\title{
COMMERCIAL FATTENING OF BUFFALO CALVES FOR ECONOMIC MEAT PRODUCTION
}

\author{
J. Banjade ${ }^{1 *}$, N. R. Devkota ${ }^{2}$, D. K. Yadav ${ }^{1}$ and N. P. Chaudhry ${ }^{1}$ \\ ${ }^{1}$ Regional Agricultural Research Station, Khajura, Banke \\ ${ }^{2}$ Agriculture and Forest University, Rampur, Chitwan \\ (*email:banjadej@gmail.com)
}

\begin{abstract}
An experiment was conducted on buffalo calves at Livestock farm of Regional Agriculture Research Station, Khajura, Nepal aiming to strengthen practice of commercial fattening. Experiment was done for a period of 7 months during the year 2015 with the main objective to develop low cost buffalo fattening technology emphasizing feeding management. Sixteen male buffalo calves aged 10-12 months were purchased from livestock haat bazaar at Rambhapur, Banke district and from farmers' field. The experiment was conducted in a Randomized Complete Block Design with 4 treatments each replicated four times. The treatment details were T1: Control-Farmer's practice, T2: Feed $1+$ roughage adlib (straw and green at 3:1 ratio), T3: Feed 2 (Urea 2\% and molasses $10 \%$ of concentrate) + roughage ad lib (straw and green at 3:1 ratio),T4: Feed 3 (Oil seed cakes $20 \%$, soybean cake $10 \%$, urea 1\%, Molasses $5 \%$ of concentrate) + roughage ad lib (straw and green at 3:1 ratio). The dry matter requirement was fulfilled at the rate of $3 \%$ of body weight. The concentrate was supplied at the rate of $25 \%$ of total dry matter requirement and rest were fulfilled from roughages i.e straw and green forage at the ratio of 3:1. The buffalo calves were vaccinated against FMD and HS. Drenching was done at the beginning and during middle of the experiment. The results showed that the significantly higher average daily gain (g) was found for T2 (508.34 g) followed by T4 (503.57). Based on economic analysis the net benefit per animal was found highest on T3 i.e urea molasses supplemented group without soybean cake supplementation Rs 2853.
\end{abstract}

Keywords: fattening, dry matter, buffalo

\section{INTRODUCTION}

Buffalo is one of the important commodities in the Nepalese farming system. Buffalo meat contributes about $58.3 \%$ of total meat production of Nepal (MOAC, 2015). It is the cheap source of animal protein for the people as compared to other meat like goat, sheep, pig and poultry. Buffalo meat demand is higher in Kathmandu, Pokhara and other larger cities of Nepal and supplied to these cities from various parts of Nepal like Banke, Nawalparasi, Siraha, and Bara districts of Nepal. Weekly livestock haatbazar are operated in these districts. Farmers sell their animals on haatbazar and traders purchase male buffaloes. Similarly, buffalo meat processing plants has been established in Bardiya and Bara districts of Nepal. These processed meats have been transported to China via Calcutta, India. There is a huge demand of male buffalo in the country for meat purpose. The demand of buffalo meat is not fulfilled yet (Devkota and Kolachapati, 2008). Buffalo 
meat contains low amount of cholesterol so more people are attracted to buffalo meat. Sinclair et al., 1982 reported that cholesterol content in buffalo meat is (46\%), sheep $(68 \%)$ and goat $(58 \%)$.

Most of the buffalo meat is produced from aged buffalo which have been used as draft (males) and milking (females). There is demand for the improvement in efficiency of buffalo meat production. The alternative use of young male calves may have advantage over old animals if they can be reared faster by feeding of nutritious diets. Kumagai et al 2012 indicated that $0.45 \mathrm{~kg} /$ day gain could be provided in crossbred male buffalo calves (Murrah x Nepal native buffalo) supplemented with limited amounts of concentrate at 0.75 $\%$ of their body weight (BW) from 128 to $250 \mathrm{Kg}$ and higher daily gain, $0.72 \mathrm{~kg}$, was attained by increasing the concentrate amount at $1.5 \%$ of Body weight. Previous studies indicated that average daily gain of buffaloes ranged between 0.433 and $0.780 \mathrm{~kg}$ (El-Feel et al., 1993, Gigli et al., 1993, Omar et al., 1993, Sadek et al., 1993 and Mehrez et al., 1993).

Devkota and Kolachapati (2008) reported that 20 buffalo calves reared for a period 6 month and 10 month under two feeding system only forage based and forage plus concentrate 200 gms per head per day. The calf reared for 180 days under two feeding system showed Net profit per animal on forage based is Rs. 716.64 and forage plus concentrate supplementation had Rs 935.98 only. Similarly, on 300 days on two systems showed net profit Rs 539.41 and 547.57 respectively. Therefore, calf rearing for shorter period (180 days) was found profitable under two feeding system.

The Buffalo calf fattening could be one of the income generating activities. Accordingly, small calf with the age of 10-12 months can be purchased from local markets and reared for 6-7 months and could be sold for meat purpose. Despite fattening option, Nepalese farmers have not given any attention to raise buffalo calf. Majority of farmers culled male buffalo calf to increase the milk production. Devkota and Kolachapati (2008) reported buffalo calf fattening using only forage based and little concentrate supplementation on forage based so there is scope of research on growth performance of buffalo calf on increasing concentrate supplementation in their diet. Therefore, this study was conducted to fatten the buffalo calves for economic meat production with development of buffalo fattening technology using low cost feed stuff and identify the effect of concentrate supplementation on growth performance of buffalo calves and its economics.

\section{MATERIALS AND METHODS}

An experiment on commercial fattening of Buffalo calves was conducted on livestock Farm of Regional Agriculture Research Station, Khajura, Banke for a period of 7 months from 10 March 2015 to 6 October 2015. Sixteen Buffalo calves aged 10-12 months were purchased from weekly haat bazaar at Rambhapur, Banke and from Farmer's field drenched with Oxanide-L @ $10 \mathrm{mg} / \mathrm{kg}$ body wt on 13 March2015. Prior drenching, the buffalo calves were vaccinated against FMD@3 ml subcutaneously on 11 March 2015. Similarly, H.S. and B.Q. combined vaccine was given@ $5 \mathrm{ml}$ sub cutaneously on 17 March 2015. The experiment was conducted in a Randomized Complete Block Design 
(RCBD) with 4 treatments and 4 replications. Dry matter requirement was fulfilled @ $3 \%$ of the body weight. The treatment detail is as followed.

- T1: Control- Farmer's Practice (Straw and green forage with little concentrate i.e. rice bran)

- T2: Feed 1 (Maize-40 \%, Rice polish- 15\%, Soybean cake 20\%, Rapesseed meal $18 \%$, Mineral mixture $1 \%$, Molasses $5 \%$ and salt $1 \%$ ) + Roughage adlib (Straw and green at 3: 1 ratio)

- $\quad$ T3: Feed 2 (Maize-41 \%, Rice polish- $20 \%$, Rapesseed meal $25 \%$, Mineral mixture $1 \%$, Molasses $10 \%$, urea $2 \%$ and salt $1 \%$ ) (Urea and molasses) + Roughage adlib (Straw and green at 3:1 ratio)

- T4: Feed 3(Maize-47 \%, Rice polish- 15\%, Soybean cake 10\%, Rape seed meal $20 \%$, Mineral mixture $1 \%$, Molasses $5 \%$, urea $1 \%$ and salt $1 \%$ ) (Oil seed cakes) + Roughage adlib (Straw and green at 3:1 ratio).

Concentrate was supplied @ $25 \%$ of total dry matter requirement. The feed compositions in different feeds were as followed. The concentrate mixture having 20\% Crude protein level has been formulated.

Table: Different composition of feed

\begin{tabular}{lll}
\hline Feed 1 & Feed 2 & Feed 3 \\
\hline Maize: 40 parts & Maize: 41 parts & Maize: 47 parts \\
Rice Polish: 15 parts & Rice Polish: 20 parts & Rice Polish: 15 parts \\
Soybean cake: 20 parts & Rape seed meal: 25 parts & Soybean cake: 10 parts \\
Rape seed: 18 parts & Mineral mix: 1 parts & Rape seed meal: 20 parts \\
Mineral mix: 1 parts & Molasses: 10 parts & Mineral mix: 1 parts \\
Molasses: 5 parts & Urea: 2 parts & Molasses: 5 parts \\
Salt: 1 parts & Salt : 1 parts & Urea: 1 parts \\
\hline
\end{tabular}

\section{Observations}

Animals were adapted for a period of 7 days as a adaptation period before the initiation of experiment. All the animals were weighed at initial and fortnight intervals. The daily feed intake, feed conversion ratio wasnoted, and economic analysis was done at the end of experiment. All the collected data were analyzed using a statistical software MSTAT-C and Microsoft excel program.

\section{RESULTS AND DISCUSSION}

\section{Chemical composition of Feedstuff}

The samples of feed ingredients, prepared compound feed was sent to the Animal Nutrition Division, Khumaltar, Lalitpur for proximate analysis. Representative samples were analyzed for dry matter (DM), crude protein $(\mathrm{CP})$, crude fibre $(\mathrm{CF})$, and total ash contents (TA). The DM was determined by oven drying at $100^{\circ} \mathrm{C}$ for $10 \mathrm{hrs}$. Crude protein of the samples was determined using the Kjeldahl method. Ash content was determined by ashing at $550^{\circ} \mathrm{C}$ in a muffle furnace for $16 \mathrm{hrs}$ (AOAC, 1980). Crude fibre of the samples 
was determined using the Van Soest method (Goering, H.K. and Van Soest, 1970). The detail of chemical composition of feed stuff is presented in (Table1).

Table 1: Chemical Composition of feed stuff

\begin{tabular}{llllllll}
\hline S.N. & $\begin{array}{l}\text { Name } \\
\text { ingredient }\end{array}$ & $\begin{array}{l}\text { of } \\
\text { Dry } \\
\text { matter } \\
(\mathbf{\%})\end{array}$ & $\begin{array}{l}\text { Crude } \\
\text { Protein } \\
\text { (CP) } \%\end{array}$ & $\begin{array}{l}\text { Crude } \\
\text { Fiber } \\
\text { (CF) } \%\end{array}$ & $\begin{array}{l}\text { Total } \\
\text { Ash \% }\end{array}$ & $\begin{array}{l}\text { Organic } \\
\text { matter } \\
\text { \% }\end{array}$ & (OM) \\
\hline $\mathbf{1}$ & Maize & 90.48 & 7.56 & 5.31 & 2.05 & 97.95 & \\
$\mathbf{2}$ & Calf feed 1 & 89.69 & 18.79 & 6.58 & 6.23 & 93.77 & \\
$\mathbf{3}$ & Calf feed 2 & 86.67 & 17.54 & 5.46 & 8.13 & 91.87 & \\
$\mathbf{4}$ & Calf feed 3 & 88.06 & 16.49 & 5.59 & 5.69 & 94.31 & \\
$\mathbf{5}$ & Soybean cake & 90.27 & 44.39 & 8.67 & 7.45 & 92.55 & \\
$\mathbf{6}$ & Mustard cake & 91.49 & 30.16 & 11.58 & 8.84 & 91.16 & \\
\hline
\end{tabular}

\section{Dry Matter Intake}

The dry matter intake of buffalo calves in different treatment groups is presented in (Table 2 ). The dry matter intake through green grass was found highest in treatment 2 and concentrate intake was highest in treatment 2 followed by treatment 4 and treatment 3 . The highest dry matter intake was found in treatment 2 followed by T4 and T3 respectively.

Table 2: Dry matter intake by different treatment groups

\begin{tabular}{|c|c|c|c|c|}
\hline \multirow[t]{2}{*}{ Treatments } & \multicolumn{4}{|c|}{ Total DM intake $($ Mean \pm SD) } \\
\hline & $\begin{array}{l}\text { Green grass } \\
(\mathrm{Kg})\end{array}$ & Straw (Kg) & $\begin{array}{l}\text { Concentrate } \\
\text { (Kg) }\end{array}$ & Total \\
\hline \multicolumn{5}{|l|}{ T1 } \\
\hline $\mathrm{T} 2$ & $179.96 \pm 29.53$ & $411.85 \pm 86.67$ & $228.92 \pm 45.9$ & $820.23 \pm 160.43$ \\
\hline $\mathrm{T} 3$ & $162.03 \pm 12.79$ & $358.75 \pm 45.7$ & $125.04 \pm 26.0$ & $645.83 \pm 62.78$ \\
\hline $\mathrm{T} 4$ & $168.07 \pm 26.64$ & $411.85 \pm 76.68$ & $197.20 \pm 35.86$ & $777.12 \pm 137.31$ \\
\hline
\end{tabular}

The average daily dry matter intake in treatment T2, T3 and T4 were 3.9, 3.07 and 3.7 \% of body weight.

\section{Growth rate}

There was no significant difference $(\mathrm{P}>0.05)$ on initial body weight of animals on different treatments. The significantly difference body weight was found on final body weight $(\mathrm{P}<0.05)$. The highest body weight was found for $\mathrm{T} 2$ i.e. $221.4 \mathrm{Kg}$ followed by $\mathrm{T} 4$ $216.43 \mathrm{Kg}$, where as body weight of $\mathrm{T} 3$ and $\mathrm{T} 1$ respectively were similar and significantly difference $(\mathrm{P}<0.01)$ on average daily weight gain was found highest on $\mathrm{T} 2$ (508.34 g /day) followed by T4 (503.57 g/day), T3 (372.15 g/day), and T1( 285.71 $\mathrm{g} /$ day) respectively (Table 3 ). 
Nepalese Vet J. 34: 51-59

Table 3: Body weight of animals in different treatment groups

\begin{tabular}{|c|c|c|c|c|c|c|}
\hline Treatments & $\begin{array}{l}\text { Initial } \\
\text { weight ( } \mathrm{Kg} \text { ) }\end{array}$ & Body & $\begin{array}{l}\text { Final } \\
\text { weight (Kg) }\end{array}$ & Body & $\begin{array}{l}\text { Average } \\
\text { Weight } \\
\text { (ADG) }\end{array}$ & $\begin{array}{r}\text { daily } \\
\text { gain }\end{array}$ \\
\hline T1 & 112.45 & & $172.45^{b}$ & & $285.71^{b}$ & \\
\hline $\mathbf{T} 2$ & 114.65 & & $221.4^{\mathrm{a}}$ & & $508.34^{\mathrm{a}}$ & \\
\hline T3 & 113.63 & & $191.78^{a b}$ & & $372.15^{\mathrm{b}}$ & \\
\hline T4 & 110.68 & & $216.43^{\mathrm{a}}$ & & $503.57^{\mathrm{a}}$ & \\
\hline Significance & NS & & $(\mathrm{P}<0.05)$ & & $(\mathrm{P}<0.01)$ & \\
\hline $\mathrm{CV}$ & 5.34 & & 9.27 & & 14.65 & \\
\hline Grand mean & 112.85 & & 200.51 & & 417.44 & \\
\hline
\end{tabular}

\section{Feed Conversion Ratio}

The feed conversion ratio of male calves during fattening period in different feeding regimes has been presented in (Table 4). The feed conversion ratio in treatment 2, 3, and 4 were $7.68,8.26$ and 7.34 respectively. Better feed conversion ratio was found for treatment (Table 4).

Table 4:Feed conversion ratio in fattening male buffalo calves

\begin{tabular}{|c|c|c|c|}
\hline Treatments & $\begin{array}{l}\text { Total DM intake } \\
\text { (Kg) }\end{array}$ & $\begin{array}{l}\text { Total Live weight } \\
\text { gain (Kg) }\end{array}$ & $\begin{array}{lr}\text { Feed } & \text { conversion } \\
\text { ratio } & \text { (Kg } \quad \mathrm{DM} / \mathrm{Kg} \\
\text { LWG) } & \end{array}$ \\
\hline T1 & & & \\
\hline T2 & 820.23 & 106.75 & 7.68 \\
\hline T3 & 645.83 & 78.15 & 8.26 \\
\hline T4 & 777.12 & 105.75 & 7.34 \\
\hline
\end{tabular}

\section{Economic Analysis}

The cost of fattening calves in different feeding regimes and output has been presented in (Table5). The net benefit (Rs) per animal was found highest in treatment 3 i.e. Rs 2853.53 per animal followed by T4, T1 and T2 i.e 2574.66, 1246 and 598.24 respectively.

Table 5: Economic Analysis of fattening male buffalo calves (Mean \pm S.D.)

\begin{tabular}{llllll}
\hline S.N. & $\begin{array}{l}\text { Treatment } \\
\text { groups }\end{array}$ & Total cost (NRs) & $\begin{array}{l}\text { Total } \\
\text { (NRs) }\end{array}$ & output & Net benefit (NRs) \\
\hline $\mathbf{1}$ & T1 & $15998.33 \pm 2355.31$ & $17245 \pm 2396.67$ & $1246 \pm 867.65$ \\
$\mathbf{2}$ & T2 & $21541.76 \pm 3726.57$ & $22140 \pm 3261.87$ & $598.24 \pm 772.63$ \\
$\mathbf{3}$ & T3 & $16323.98 \pm 1049.61$ & $19178 \pm 1158.23$ & $2853.53 \pm 747.71$ \\
$\mathbf{4}$ & T4 & $19506.99 \pm 2879.16$ & $21643 \pm 2832.51$ & $2574.66 \pm 1023.30$ \\
\hline
\end{tabular}

Note: concentrate @ Rs 38.3/kg for T2,30.33/kg for T3, T1 and 34.43/kg for T4, Rice straw @ $1 / \mathrm{kg}$ and green grass @ $5 / \mathrm{kg}$ on DM basis. The green grass cost also includes 
labor cost for calf management. The buffalo calf has been estimated @ Rs 100/kg live weight.

\section{DISCUSSION}

El-Ashry et al., (1972) showed that Feed conversion values for buffalo calves were 11.5, 5.6 and $5.7 \mathrm{Kg}$ for roughages solely supplemented, $50 \%$ concentrate (1: 1 roughages and concentrate supplemented) and $80 \%$ concentrate ration and $20 \%$ roughages supplemented group. The FCR Value in $50 \%, 80 \%$ concentrate supplemented group is less and roughages only has high comparable to present study.

Feeding $20 \%$ less CP than NRC (2001) recommendation for small cattle breeds are adequate for $400 \mathrm{~g}$ growth rate of Bhadawari calves and had no adverse effect on feed intake and dietary fiber utilization (Singhet al., 2009). The experiment on fattening of buffalo calves was conducted in three categories of ration i.e (T1) mixed grass and straw adlibitum, (T2) mixed grass and rice straw and concentrate ration (roughage and concentrate ration (70: 30 in DM basis) and (T3) mixed grass and rice straw and concentrate ration (50:50 in DM basis). The body weight gain for T1, T2, and T3 were 202,455 and $618 \mathrm{gm} /$ day. The more economical combination was mixed grass and rice straw, concentrate supplementation (70: 30 in DM basis) (Banstola et al., 2004). The feeding combination of roughage and concentrate (70: 30 in DM basis) growth rate is at par with the present findings.

Devkota and Kolachapati (2008) reported that buffalo calves were reared on on-farm condition using 15 buffalo calves in three treatment groups with three animals in each treatment replicated five times. The treatment combination was urea treated rice straw with $1.5 \mathrm{~kg}$ Berseem and little molasses (5\% of dry matter requirement), urea untreated rice straw with little concentrate ( $10 \%$ of total dry matter requirement) and berseem forage ( straw and berseem in the ratio of 1:1), untreated rice straw and berseem ( 1:1 ratio out of which $80 \%$ dry matter from straw and $20 \%$ from berseem) for a period of 150 days found per $\mathrm{kg}$ meat production cost was 67.77 on untreated rice straw and berseem supplemented group . The daily weight gains were $360 \mathrm{~g}, 323$ and $305 \mathrm{~g}$ respectively. Net profit per $\mathrm{kg}$ meat production was found highest Rs 39.61 on urea non-treated and berseem feeding group. The growth rate found better on urea treated cum berseem feeding and molasses supplemented group. On molasses unavailability, condtion straw and berseem could be used for feeding. The growth rates in present findings were greater than reported by Devkota and Kolachayapati (2008).

Response of different level of concentrate feeding on local male buffalo calves was conducted at RARS Lumle for a period of 210 days, the ratio of concentrate to roughagesassigned in the three treatments were 40:60, 50:50 and 60: 40. The average daily gain were $645 \mathrm{~g}, 728 \mathrm{~g}, 747 \mathrm{~g}$, respectively and the net return per animal were Rs 4528 , 4330 and 4630 in three treatment groups respectively (Jha et al., 2004). The growth rate on present study is $508 \mathrm{~g}$ /day in concentrate to roughages ratio $(25: 75 \%)$ which is less than (40: 60 concentrate and forage ration)supplementation reported by Jha et al., 2006. 
Meat production potential and carcass characteristics of eight local male buffalo calves were studied. A group of 4 calves (treatment group) were kept under concentrate feeding, whereas, another group having similar number of calves (control group) were kept under general village feeding practices. The calves on treatment group received $70 \%$ of total requirement was consisted from concentrate and $30 \%$ from roughage. The animals of treatment group received significantly $(\mathrm{P}<0.05)$ higher daily weight gain $(719 \mathrm{~g})$ compared to control group (469 gm) (Rana et al., 2000). Increasing the concentrate level increased the weight gain, the weight gain in this treatment group is higher where concentrate had contribution of $70 \%$ dry matter requirement. The present study has 508 gm average daily gain on $25 \%$ dry matter requirement fulfillment from concentrate and rest is from roughages.

The economics of buffalo meat production was compared at veal stage $(200 \mathrm{~kg}$ body weight) and at beef stage (300 kg weight) under four feeding planes. The calves under $6 \mathrm{hr}$ grazing and concentrate supplementation@1\% of body weight and adlib bhusa feeding found to more economical i.e net return per animal was found to be Rs. 1898. Concentrate mixture consisting of barley grains $(50 \%)$, deoiled rice bran $(10 \%)$, deoiled sunflower cake $(20 \%)$, deoiled mustard cake $(17 \%)$, mineral mixture $2 \%$ and common salt $1 \%$. The fodder to concentrate ratio was maintained at 60: 40 in all these treatments (Kamboj et al., 2007). The present research net return per animal is similar with reported by Kamboj et $a l .,(2007)$ in urea molasses supplemented group.

Eighteen male calves from native, crossbred (Holstein *Native) and buffalo (six animals for each group) with an average body weight (BW) of $160 \mathrm{Kg}$ were fatten till $300 \mathrm{~kg}$. Total mixed ration feed ( $5 \%$ over animal appetite) offered to each animal 3 times daily. The average daily gain (gm/day) found to be 777, 641 and 912 for buffalo, native and crossbred (HN). Similarly, the significant dry matter intakes (Kg/day) were 5.58, 5.31, and 6.3 and feed conversion ratio was 7.2, 8.3 and 6.9 which was found non-significant (Azary et al., 2007). The dry matter intake found higher than present study, but feed conversion efficiency was found similar.

Growth rate of buffalo calves reported by Thapa et al., (1997) was $389 \mathrm{~g}$ per day fed on concentrate. Similarly, the growth rate varied from 200 to $550 \mathrm{~g}$ per day (Langer et al., 1985; Punia and Sharma 1988; Kakker et al., 1991). However, Pathak et al. (1987) observed a daily weight gain of $576 \mathrm{~g}$ on high protein and high energy diet. These growth rate are comparable with present findings.

\section{CONCLUSION}

The highest average daily gain was found in soybean cake supplemented group, but the economical analysis showed that urea and molasses supplemented group had the highest net benefit, so fattening of buffalo calves could be done using urea, molasses feed mixture without soya cake supplementation meeting $25 \%$ dry matter requirement from concentrate and $75 \%$ from roughages (straw and green forages in 3:1 ratio). There is still scope of research on soybean cake supplementation in concentrate ration for further verification. 


\section{ACKNOWLEDGEMENTS}

The authors are thankful to Nepal Agriculture Research Council for providing research grant for conducting the research and Regional Director, Regional Agriculture Research Station, Khajura, Banke for facilitating the conduction of research.

\section{REFERENCES}

AOAC (1980) Official methods of analysis. Association of Official Analysis Chemists, Washington DC, U.S.A.

Azary, A.M., Manafiazar, G., Razagzadeh, S. and Amini-jabalkandi, J.(2007). Comparing fattening performance of Azeri buffalo, Native and Crossbred (native *Holstein) male calves in west Azerbaijan-Iran. Italian Journal of Animal Science, 6: 12521255.

Banstola, B.R., Shrestha, H.R., Thapa, M.S.and Osti N.P. (2004). Fattening of Buffalo calves for economic meat Production. In B.R. Joshi, D. Pariyar, S.P. Neopane, T.B. Gurung, K.P. Poudel, B.S. Shrestha (eds.), Proceedings of Sixth National Conference on Livestock and Fisheries Research, Khumaltar, Lalitpur, 1-2 July (pp140-145). Nepal Agriculture Research Council.

Devkota, N.R., and Kolachayapati, M.R. (2008). Forage based Buffalo fattening technology for meat Production. Institute of Agriculture and Animal Science, Rampur/ National Agriculture and Research Development Fund, Kathmandu pp 28-33.

EI-Ashry, M.A., Mogawer, H.H. and El-Khishin, S.S., (1972). Comparative study, meat production from cattle and buffalo male calves. Egypt. J. Anim. Prod., 12: 99.

El-Feel, F.M.R., Hassan, H.A., Morsy, N.H.A. and Fahmy, S.T.M. (1993). Performance of buffalo calves raised under the upper Egypt conditions as affected by level of feeding, season of calving and body weight. Proceedings of the International Symposium on Prospects of Buffalo Production in the Mediterranean/ Middle East, Cairo, Egypt, Nov. 9- 12, (1992), pp. 133-136.

Gigli, S., Carretta, A., Failla, S. and F. Napolitano (1993). Meat production in Italian male buffaloes with two nutritive levels and slaughtered at 4 different ages. In vita performance, carcass characteristics and meat quality. Proceedings of the International Symposium on Prospects of Buffalo Production in the Mediterranean/ Middle East, Cairo, Egypt, Nov. 9-12, (1992), pp. 124-128.

Goering, H.K. and Van Soest (1970) Forage fibre analysis apparatus, reagents, procedures and some application, ARS, USDA, Handbook N 397

Jha, P.K., Shrestha B.S. and Rana, R.S. (2004). Response to Different Level of Concentrate Feeding on Meat Production of Local Male Buffalo Calves. In B.R. Joshi, D. Pariyar, S.P. Neopane, T.B. Gurung, K.P. Poudel, B.S. Shrestha (eds.), Proceedings of Sixth National Conference on Livestock and Fisheries Research, Khumaltar, Lalitpur, 1-2 July (pp133-139). Nepal Agriculture Research Council.

Kakker, V.K., Malik, N.S. and Makar, G.S. (1991). Protein Requirement of male buffalo calves. Indian Journal of Animal Nutrition, 8: 191-194.

Kamboj, M.L., Paul S.S., Chawla, D.S. and Prasad S. (2007). Economics of rearing niliravi male buffalo calves under four feeding regimes for meat production. Indian Journal of Animal Research.41(3): 200-203. 
Kumagai, H., Baral, B.R., Shiino, T., Devkota, N.R., Oishi, K., Hirooka H., Kolachhapati, M.R., Tiwari, I.C.P., (2012). Effects of Plane of Nutrition on Growth, Feed intake, Digestibility and Nitrogen Balance in Murrah graded male Buffalo (Bubalus bubalis) calves in Nepal. Animal Science Journal, 83(1): 50-54.

Langer, P.N., Bakshi, M.P.S., and Saini, K.S. (1985). Growth Performance of buffalo heifers raised on urea-wheat straw rations. Indian Journal of Animal Sciences,55: 1053-1059.

Mehrez, A.Z., El-Ayouty, S.A., Ibrahim, Z.M.K., and Younis, A.A. (1993). Effect of feeding level on meat production from buffalo calves: 2- Growth performance, feed utilization, and carcass quality. Proceedings of the International Symposium on Prospects of Buffalo Production in the Mediterranean/ Middle East, Cairo, Egypt, Nov. 9-12, (1992), pp. 137- 140.

MOAC, 2015. Selected Indicators of Nepalese Agriculture and Population. Agri Business Promotion and Statistics Division, Ministry of Agriculture and Cooperatives. Singha Durbar, Kathmandu, Nepal.

Omar, S.S., Houria, M.A. and Baraghite, G.A. (1993). Studies on growth performance of male buffalo and bovine calves under commercial fattening farms in Menofiya province. Egyptian J. of Anim. Prod., 30(2):117-128.

Pathak, N.N., Ranjhan, S.K. and Baruah, K.K. (1987). Growth responses feed efficiency and carcass characteristics of Indian buffalo (Bubalus bubalis) calves fattened on different plane of Nutrition. Buffalo Bulletin, 6: 77-82.

Punia, B.S. and Sharma, D.D. (1988). Effect of dietary energy source in complete feed on digestion and Live weight gain in buffalo and crossbred cattle calves. Indian Journal of Animal Science,58: 715-720.

Rana, R.S., Amatya, N., and Shrestha, H.R. (2000). Effect of Concentrate feeding on meat Production of Local Male Buffalo Calves. In: S.P. Neopane, A.K. Rai, R. Bhurtel (eds.), Proceedings of the Fourth National Workshop on Livestock and Fisheries Research in Nepal, Khumaltar, Lalitpur, 24-26 April (pp 132-1139). Nepal Agriculture Research Council.

Sadek, R.R., El-Kholy, A.F., Nigm, A.A., Ibrahim, M.A.M. and Morsy, M.A. (1993). Daily gain, feed conversion and carcass characteristics of Friesian and buffalo males fed on Flavomycin. Proceedings of the International Symposium on "Prospects of Buffalo Production in the Mediterranean/ Middle East", Cairo, Egypt, Nov. 9-12, (1992), pp. 129- 132.

Sinclair, A.J., Slattery W.J. and Dea K.O. (1982). The analysis of Polysaturated fatty acids in meat by capillary gas liquid chromatography. Journal of Science and Good Agriculture, 33: 771-76.

Singh, S.S., Kundu S., Kushwaha B.P. and Maity S.B. (2009). Response of Bhadawari Buffalo calves to dietary feed intake, nutrients utilization, $\mathrm{N}$ balance, nutrient efficiency and growth performance. Indian Journal of Animal Science, 79(12): 1233-1237.

Thapa, M.S., Shreshta, H.R. and Kuwnar, B.S. (1997). Annual Technical Report, Nepal Agriculture Research Council, Bovine Research Program, Khumaltar, Lalitpur, Nepal. 